\title{
Topical Oil Dosage Form
}

National Cancer Institute

\section{Source}

National Cancer Institute. Topical Oil Dosage Form. NCI Thesaurus. Code C91191.

A oil intended for administration to a body surface. 